\title{
A Theoretical Investigation of Donor-Acceptor Bonding between Amines and Silylenes
}

\author{
R. T. Conlin," Dianna Laakso, and Paul Marshall* \\ Department of Chemistry, University of North Texas, P.O. Box 5068, \\ Denton, Texas 76203-5068
}

Received September 23, $1993^{\circ}$

\begin{abstract}
The dative $\mathrm{Si}-\mathrm{N}$ bond dissociation enthalpy $D_{0}$ in $\mathrm{SiH}_{2} \leftarrow \mathrm{NH}_{3}$ has been estimated as $97 \pm 10$ $\mathrm{kJ} \mathrm{mol}^{-1}$ at the $\mathrm{G} 2$ level of theory. $D_{0}$ values for substituted analogs and cyclic complexes closed by intramolecular $\mathrm{Si}-\mathrm{N}$ bonds have been obtained by means of isodesmic reactions, and strains in four-, five-, and six-membered rings are shown to be small. $D_{0}$ in $\mathrm{SiH}_{2} \leftarrow\left(\mathrm{NH}_{3}\right)_{2}$ is estimated to be $7 \pm 20 \mathrm{~kJ} \mathrm{~mol}^{-1}$. Kinetic implications of $D_{0}$ are discussed. Vibrational frequencies and UV/visible spectra of various silylenes and silaylides are predicted, to obtain changes in the $S_{0}$ $\rightarrow \mathrm{S}_{1}$ energy relative to $\mathrm{SiH}_{2}$. Ylide formation is seen to increase this gap, and CIS/6-31+G* results suggest that complexation of $\mathrm{SiH}_{2}$ with $\mathrm{NH}_{3}$ shifts the absorption from 485 to $301 \mathrm{~nm}$.
\end{abstract}

\section{Introduction}

This work is an ab initio study of the thermochemistry and spectroscopy of dative bonds ${ }^{1}$ between amines and silylenes (silanediyls). These bonds are formed through donation of the lone electron pair on the $\mathrm{N}$ atom into the empty $\mathrm{p}$ orbital on the $\mathrm{Si}$ atom. The existence of such bonds has recently been demonstrated in silylenes stabilized by coordination to Lewis bases, which contain intramolecular amine groups., ${ }^{2,3}$ X-ray structure determinations on these coordinate complexes containing the silaylide arrangement revealed a relatively large $\mathrm{Si}-\mathrm{N}$ separation of about $2.05 \AA .{ }^{3}$ This may be compared to the normal Si-N distance of, e.g., about $1.72 \AA$ calculated for silylamine. ${ }^{4}$ These complexes involve five-membered rings containing $\mathrm{Si} \leftarrow \mathrm{N}$ bonds, which are therefore a focus in this work. Similar donation of lone electron pairs on $O$ atoms into silylenes has been investigated experimentally by several groups, ${ }^{5-12}$ while Ando et al..$^{13}$ and Gillette et $a l{ }^{14}$ have studied the changes in the electronic spectrum of silylenes caused by donor-acceptor adduct formation. There have also been recent studies of the isoelectronic donor-acceptor complexes formed between amines and alanes. 1,15

- Abstract published in Advance ACS Abstracts, January 15, 1994. (1) Haaland, A. Angew. Chem., Int. Ed. Engl. 1989, 28, 992.

(2) Corriu, R., Lanneau, G.; Priou, C. Angew. Chem., Int. Ed. Engl. $1991,30,1130$

(3) Probst, R.; Leis, C.; Gamper, S.; Herdtweck, E.; Zybill, C.; Auner, N. Angew. Chem., Int. Ed. Engl. 1991, 30, 1132.

(4) Raghavachari, K.; Chandrasekhar, J., Gordon, M. S.; Dykema, K. J. J. Am. Chem. Soc. 1984, 106, 5853.

(5) Tzeng, D.; Weber, W. P. J. Am. Chem. Soc. 1980, 102, 6095.

(6) Gu, T. Y.; Weber, W. P. J. Am. Chem. Soc. 1980, 102, 1641

(7) Steele, K. P.; Weber, W. P. J. Am. Chem. Soc. 1980, 102, 6095

(8) Steele, K. P., Tzeng, D.; Weber, W. P. J. Organomet. Chem. 1982 $231,291$.

(9) Ando, W.; Hagiwara, K.; Sekiguchi, A. Organometallics 1987, 6, 2270

(10) Gillette, G. R.; Noren, G. H.; West, R. Organometallics 1987, 6, 2617.

(11) Levin, G.; Das, P. K.; Bilgrien, C.; Lee, C. L. Organometallics 1989, 8, 1206.

(12) Baggott, J. E.; Blitz, M. A.; Frey, H. M.; Lightfoot, P. D.; Walsh, R. Int. J. Chem. Kinet. 1992, 24, 127.

(13) Ando, W.; Hagiwara, K,; Sekiguchi, A.; Sakakibari, A.; Yoshida, H. Organometallics 1988, 7, 558 . 487.

(14) Gillette, G. R.; Noren, G. H.; West, R. Organometallics 1989, 8,
The UV-visible spectra of several silylenes have previously been analyzed in terms of the Hartree-Fock wave functions of the ground and first excited singlet states by Apeloig and Karni: ${ }^{16}$ here we assess the usefulness of the CIS method recently described by Pople and co-workers ${ }^{17}$ and compare results from both approaches with experimental data for free silylenes and silylenes complexed to amines.

Silylene-amine bonding is of potential practical significance in plasma-enhanced chemical vapor deposition of silicon nitride from ammonia/silane mixtures, where the gas-phase reaction of $\mathrm{SiH}_{2}$ with $\mathrm{NH}_{3}$ may be an important step. ${ }^{18,19}$ The theoretical work of Raghavachari et al. predicts that $\mathrm{SiH}_{2}$ and $\mathrm{NH}_{3}$ initially combine to form a silaylide adduct, which has a significant barrier to isomerization to the more stable $\mathrm{SiH}_{3} \mathrm{NH}_{2}{ }^{4}$ Part of the present work forecasts the vibrational and electronic properties to aid the design of experiments to study the $\mathrm{SiH}_{2}+\mathrm{NH}_{3}$ reaction. The results obtained are also considered in the context of recent experiments on possible cyclic amine/silylene complexes. ${ }^{20}$ Strain energies for four-, five-, and six-membered rings containing $\mathrm{Si} \leftarrow \mathrm{N}$ dative bonds are estimated, and kinetic implications of the thermochemistry are discussed.

\section{Theoretical Method}

Results were obtained by use of the GAUSSIAN90 program, ${ }^{21}$ implemented on a VAX 6310 and a Solbourne $5 \mathrm{E} / 902$ computer. Standard $a b$ initio molecular orbital theory was employed to optimize the energy as a function of nuclear coordinates, ${ }^{22}$ and calculations were performed using the split-valence $3-21 G\left({ }^{*}\right)$,

(15) Marsh, C. M. B.; Hamilton, T. P.; Xie, Y.; Schaefer, H. F., III. J. Chem. Phys. 1992, 96, 5310.

(16) Apeloig, Y,; Karni, M. J. Chem. Soc., Chem. Commun. 1985, 1048.

(17) Foresman, J. B.; Head-Gordon, M.; Pople, J. A.; Frisch, M. J. J. Phys. Chem. 1992, 96, 135.

(18) Beach, D. B.; Jasinski, J. M. J. Phys. Chem. 1990, 94, 3019.

(19) Kushner, M. J. J. Appl. Phys. 1992, 71, 4173.

(20) Marghall, P.; Bott, S. G.; Tan, C.; Wagenseller, P. E.; Wang, Y.; Conlin, R. T. To be published.

(21) Frisch, M. J.; Head-Gordon, M.; Trucks, G. W.; Foresman, J. B.; Schlegel, H. B.; Raghavachari, K.; Robb, M. A.; Binkley, J. S.; Gonzalez, C.; Defrees, D. J.; Fox, D. J.; Whiteside, R. A.; Seeger, R.; Melius, C. F.; Baker, J.; Martin, R. L.; Kahn, L. R.; Stewart, J. J. P.; Topiol, S.; Pople, J. A. GAUSSIAN 90; Gaussian: Pittsburgh, 1990.

(22) Hehre, W. J.; Radom, L.; Schleyer, P. v. R.; Pople, J. A. Ab Initio Molecular Orbital Theory; Wiley: New York, 1986. 
6-31G*, and 6-311G** atomic basis sets. The first basis set includes polarization functions on $\mathrm{Si}$, and the second includes polarization functions on all but the $\mathrm{H}$ atoms, while the third basis set includes polarization functions on all atoms. A full geometry optimization was carried out for the ground state of each closed-shell $\left(\mathrm{S}_{0}\right)$ molecule using the spin-restricted HartreeFock (RHF) method. RHF harmonic vibrational frequencies were calculated to verify each equilibrium structure as a true minimum. HF frequencies are typically about $10 \%$ higher than experimental and, thus, were scaled by a standard factor of $0.9^{22}$ before zero-point vibrational energies (ZPE) were computed.

Electronic energies were calculated for the first excited singlet $\left(S_{1}\right)$ and triplet $(T)$ states of each molecule at its $S_{0}$ RHF geometry, by means of unrestricted Hartree-Fock (UHF) theory. Spin contamination was monitored via the value of $\left\langle S^{2}\right\rangle$. Energies of the pure first excited singlets ( $E\left[S_{1}\right.$, pure $]$ ) were derived from the triplet energies and the energies of the contaminated UHF singlets (which have $\left\langle S^{2}\right\rangle \approx 1$ and are mixtures of the wave functions of the pure excited singlets and triplets) using the relation proposed by Apeloig and Karni: ${ }^{16}$

$E\left[\mathrm{~S}_{1}\right.$, pure $]=\left[2 E\left[\mathrm{~S}_{1}\right.\right.$, contaminated $\left.]-\left\langle\mathrm{S}^{2}\right\rangle E(T)\right] /\left(2-\left\langle S^{2}\right\rangle\right)$

Their fix of spin contamination is not highly satisfactory because $E\left[S_{1}\right.$, pure] becomes indeterminate as $\left\langle S^{2}\right\rangle$ approaches 2 . Accordingly, an alternative method to derive the vertical energy separation between the $S_{0}$ and $S_{1}$ states is evaluated here. The $S_{0}$ geometry was optimized at the RHF/6-31G* level and the energy gap was derived using configuration interaction with single excitations, ${ }^{17}$ with the $6-31+\mathrm{G}^{*}$ basis set. The " + " indicates the inclusion of diffuse functions that aid the description of any Rydberg character in the excited-state wave function.

For the thermochemical analysis single-point energies for ground states were obtained at the RHF/6-31G* geometries by means of second-order and fourth-order Møller-Plesset perturbation theory (MP2 and MP4) using the frozen core approximation with the 6-31G* and $6-311 \mathrm{G}^{* *}$ basis sets. Finally, the ground-state energy of the $\mathrm{H}_{3} \mathrm{~N} \rightarrow \mathrm{SiH}_{2}$ complex was computed at the Gaussian-2 (G2) level of theory. ${ }^{23-25}$ Briefly, the G2 procedure is based on MP4 energies calculated with the 6-311G** basis set at the MP2/6-31G*-optimized geometry, modified by a series of additive corrections to approximate a full QCISD(T) $/ 6-311+G(3 d f, 2 p)$ calculation.

\section{Results and Discussion}

3.1. Geometry. Six molecules were examined for the purpose of studying the $\mathrm{Si}-\mathrm{N}$ bond dissociation energy: $\mathrm{H}_{3} \mathrm{NSiH}_{2}$ (molecule A), $\left(\mathrm{H}_{3} \mathrm{~N}\right)_{2} \mathrm{SiH}_{2}(\mathbf{B}), \mathrm{CH}_{3}\left(\mathrm{H}_{2}\right) \mathrm{NSi}(\mathrm{H})$ $\mathrm{CH}_{3}$ and linear and cyclic $\mathrm{HSi}\left(\mathrm{CH}_{2}\right)_{x} \mathrm{NH}_{2}(x=2,3,4$ : C-H) (see Figures 1 and 2). Selected results of the geometry optimizations of the first two species are shown in Figure 1. For $\mathbf{A}$ the calculated $\mathrm{Si}-\mathrm{N}$ bond length increases from 2.043 to $2.089 \AA$ upon increasing the flexibility of the atomic basis set from $3-21 \mathrm{G}\left({ }^{*}\right)$ to $6-31 \mathrm{G}^{*}$ and, unlike most bonds, ${ }^{22}$ decreases when electron correlation is included at the MP2 $=$ FULL/6-31G* level, back to $2.063 \AA$. Similar decreases have been noted for the calculated Al-N separation of about $2.08 \AA$ in the isoelectronic $\mathrm{AlH}_{3} \leftarrow \mathrm{NH}_{3}$ molecule, ${ }^{15}$ as well as other dative bonds. ${ }^{22}$ These distances compare well with the measured intramolecular $\mathrm{Si}-\mathrm{N}$ separation of $2.046 \AA$ in a more complicated base-stabilized silaylide. ${ }^{3}$ For $\mathrm{CH}_{3}\left(\mathrm{H}_{2}\right) \mathrm{NSi}$ (H) $\mathrm{CH}_{3}$ the $\mathrm{Si}$ and $\mathrm{N}$ atoms are $2.027 \AA$ apart at the RHF/

(23) Pople, J. A.; Head-Gordon, M.; Fox, D. J.; Raghavachari, K.; Curtiss, L. A. J. Chem. Phys. 1989, 90, 5622 .

(24) Curtiss, L. A.; Jones, C.; Trucks, G. W.; Raghavachari, K.; Pople, J. A. J. Chem. Phys. 1990, 93, 2537.

(25) Curtiss, L. A.; Raghavachari, K.; Trucks, G. W.; Pople, J. A. J. Chem. Phys. 1991, 94, 7221.

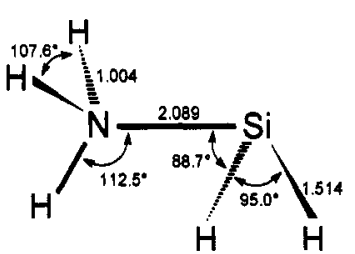

A

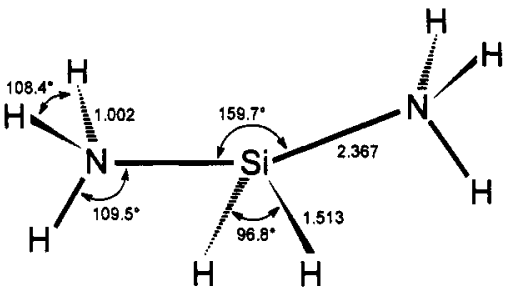

Figure 1. Structures of complexes of $\mathrm{NH}_{3}$ with $\mathrm{SiH}_{2}$, showing selected bond lengths ( $\AA$ ) and angles (deg) calculated at the HF/6-31G* level of theory.

(c)

Figure 2. Structures of the linear and cyclic silylenes HSi$\left(\mathrm{CH}_{2}\right)_{x} \mathrm{NH}_{2}(x=2,3,4)$.

3-21G(*) level, which indicates that simple alkyl substitution has little influence on the Si-N distance. The RHF/ $3-21 \mathrm{G}(*)$ distances in the cyclic species $\mathbf{D}, \mathbf{F}$, and $\mathbf{H}$ are $2.045,2.017$, and $2.018 \AA$, respectively. In $B$ the $\mathrm{Si}-\mathrm{N}$ distance is predicted at the RHF/3-21G(*) and RHF/6$31 \mathrm{G}^{*}$ levels to be 2.274 and $2.367 \AA$. As shown below, the longer $\mathrm{Si}-\mathrm{N}$ bonds in this molecule are much weaker than in the other silaylides analyzed here.

The Mulliken charges on Si and $\mathrm{N}$ in free $\mathrm{SiH}_{2}$ and $\mathrm{NH}_{3}$ at the $R H F / 6-31 \mathrm{G}^{*}$ level are +0.32 and -1.00 , respectively, and change to +0.18 and -1.02 upon formation of $\mathrm{A}$. Alternatively, if $\mathrm{H}$ atom charges are summed with heavy atoms, then the Mulliken charges on the $\mathrm{SiH}_{2}$ and $\mathrm{NH}_{3}$ groups within $\mathbf{A}$ are \pm 0.20 . Thus there is no large charge separation in the donor-acceptor complex and any description of the complex as "zwitterionic" is best regarded as a formal representation.

3.2. Vibrational Frequencies. The results of normal mode analyses for $\mathbf{A}$ and $\mathbf{B}$ are listed in Table 1. For $\mathbf{A}$ the modes below $1000 \mathrm{~cm}^{-1}$ show strong coupling between $\mathrm{SiH}_{2}$ and $\mathrm{NH}_{3}$ motions and have mixed character. $\mathrm{Si}-\mathrm{N}$ stretching is mainly in the mode predicted to lie at 833 $\mathrm{cm}^{-1}$, where it is coupled to scissoring of the $\mathrm{SiH}_{2}$ group and inversion, i.e., umbrella motion of the $\mathrm{NH}_{3}$ group. In $\mathrm{B}$, symmetric $\mathrm{Si}-\mathrm{N}$ stretching is estimated to occur at 188 $\mathrm{cm}^{-1}$ while the IR-active asymmetric stretching is found at $125 \mathrm{~cm}^{-1}$. Promising spectral regions for IR detection of $\mathbf{A}$ and $\mathbf{B}$ must contain reasonably intense absorption bands that are well-separated from the absorptions of $\mathrm{SiH}_{2}$ and $\mathrm{NH}_{3}$ that are likely to be present in an attempted synthesis of A. Such regions lie at approximately 352 and $1288 \mathrm{~cm}^{-1}$ for $A$, and for $B$ at approximately 125,511 , and $865 \mathrm{~cm}^{-1}$. The most intense features in their spectra will be the $\mathrm{Si}-\mathrm{H}$ stretching bands at $\approx 1900 \mathrm{~cm}^{-1}$, and it might 
Table 1. Calculated Vibrational Frequencies of $\mathrm{SiH}_{2} / \mathrm{NH}_{3}$ Adducts"

\begin{tabular}{|c|c|c|c|c|c|}
\hline$\nu, \mathrm{cm}^{-1}$ & $I, \mathrm{~km}^{b}$ & $\mathrm{SiH}_{2} \mathrm{NH}_{3}$ descrptn ${ }^{c}$ & $\nu, \mathrm{cm}^{-1}$ & $I, \mathrm{~km}^{b}$ & $\underset{\operatorname{descrptn}^{c}}{\mathrm{SiH}_{2}\left(\mathrm{NH}_{3}\right)_{2}}$ \\
\hline $\begin{array}{l}149 \\
352 \\
525\end{array}$ & $\begin{array}{c}0.6 \\
44 \\
0.4\end{array}$ & $\begin{array}{l}\mathrm{SiH}_{2}, \mathrm{NH}_{3} \text { rock } \\
\mathrm{NH}_{3} \text { rock } \\
\mathrm{SiH}_{2}, \mathrm{NH}_{3} \text { def, } \\
\quad \text { torsion }\end{array}$ & $\begin{array}{r}82 \\
95 \\
125\end{array}$ & $\begin{array}{c}0.0 \\
18 \\
130\end{array}$ & $\begin{array}{l}\text { torsion } \\
\text { torsion } \\
\text { asym SiN str }\end{array}$ \\
\hline $\begin{array}{l}543 \\
819 \\
833\end{array}$ & $\begin{array}{c}3.8 \\
47 \\
130\end{array}$ & $\begin{array}{l}\mathrm{SiH}_{2} \text { scis, } \mathrm{NH}_{3} \text { inv } \\
\mathrm{NH}_{3} \text { def, torsion } \\
\mathrm{SiH}_{2} \text { scis, } \mathrm{NH}_{3} \text { inv, } \\
\quad \mathrm{SiN} \text { str }\end{array}$ & $\begin{array}{l}131 \\
186 \\
188\end{array}$ & $\begin{array}{l}36 \\
9.0 \\
0.0\end{array}$ & $\begin{array}{l}\text { NSiN bend } \\
\text { torsion } \\
\text { sym SiN str }\end{array}$ \\
\hline $\begin{array}{r}984 \\
1288 \\
1646 \\
1648 \\
1929 \\
1946 \\
3321 \\
3435 \\
3440\end{array}$ & $\begin{array}{r}140 \\
210 \\
32 \\
42 \\
540 \\
379 \\
29 \\
52 \\
59\end{array}$ & $\begin{array}{l}\mathrm{HSiN} \text { bend } \\
\mathrm{NH}_{3} \text { rock } \\
\mathrm{NH}_{3} \text { def } \\
\mathrm{NH}_{3} \text { def } \\
\mathrm{SiH} \text { str } \\
\mathrm{SiH} \text { str } \\
\mathrm{NH} \text { str } \\
\mathrm{NH} \text { str } \\
\mathrm{NH} \text { str }\end{array}$ & $\begin{array}{r}389 \\
401 \\
509 \\
513 \\
830 \\
865 \\
959 \\
1166 \\
1168 \\
1650 \\
1650 \\
1651 \\
1652 \\
1918 \\
1931 \\
3331 \\
3332 \\
3455 \\
3455 \\
3457 \\
3458\end{array}$ & $\begin{array}{c}0.0 \\
0.0 \\
41 \\
58 \\
0.0 \\
170 \\
140 \\
440 \\
8.0 \\
61 \\
0.0 \\
2.4 \\
50 \\
590 \\
378 \\
22 \\
0.6 \\
1.6 \\
39 \\
2.4 \\
41\end{array}$ & $\begin{array}{l}\mathrm{NH}_{3} \text { rock } \\
\mathrm{NH}_{3} \text { rock } \\
\mathrm{NH}_{3} \text { rock } \\
\mathrm{NH}_{3} \text { rock } \\
\mathrm{SiH}_{2} \text { twist } \\
\mathrm{SiH}_{2} \text { rock } \\
\mathrm{SiH}_{2} \text { scis } \\
\mathrm{NH}_{3} \text { inv } \\
\mathrm{NH}_{3} \text { inv } \\
\mathrm{NH}_{3} \text { def } \\
\mathrm{NH}_{3} \text { def } \\
\mathrm{NH}_{3} \text { def } \\
\mathrm{NH}_{3} \text { def } \\
\mathrm{SiH} \text { str } \\
\mathrm{SiH} \text { str } \\
\mathrm{NH} \text { str } \\
\mathrm{NH} \text { str } \\
\mathrm{NH} \text { str } \\
\mathrm{NH} \text { str } \\
\mathrm{NH} \text { str } \\
\mathrm{NH} \text { str }\end{array}$ \\
\hline
\end{tabular}

${ }^{a} \mathrm{HF} / 6-31 \mathrm{G}^{*}$ frequencies scaled by a factor of $0.9 .{ }^{b} \mathrm{IR}$ absorption intensity. ' Str, stretch; def, deformation; inv, inversion; scis, scissor.

be possible to detect ylide formation using high-resolution IR spectroscopy to monitor small shifts in these $\mathrm{Si}-\mathrm{H}$ stretching frequencies.

3.3. Thermochemistry. Total energies for the species considered here are listed in Table 2 and are employed together with the ZPE to calculate $D_{0}$, the bond dissociation enthalpy at $0 \mathrm{~K}$. The $\mathrm{G} 2$ calculation of $D_{0}$ for the $\mathrm{SiH}_{2} \leftarrow \mathrm{NH}_{3}$ silaylide yields $97 \mathrm{~kJ} \mathrm{~mol}^{-1}$ (Table 3 ). Because G2 theory has usually been found to agree well with experimental data, with a target accuracy of $\pm 8 \mathrm{~kJ} \mathrm{~mol}^{-1},{ }^{25}$ we assign an approximate uncertainty of $\pm 10 \mathrm{~kJ} \mathrm{~mol}^{-1}$ to this result. Our $D_{0}$ value is close to two previous calculations: an MP4/6-31G**//HF/6-31G* result of 105 $\mathrm{kJ} \mathrm{mol}{ }^{-1}$ from Raghavachari et al. ${ }^{4}$ and a BAC-MP4 value of $109 \pm 12 \mathrm{~kJ} \mathrm{~mol}^{-1}$ by Melius. ${ }^{26}$ These values are quite close to the $D_{0}$ calculated by Marsh et al. for $\mathrm{AlH}_{3} \leftarrow \mathrm{NH}_{3}$ of $109 \mathrm{~kJ} \mathrm{~mol}^{-1}, 15$ while experiments by Haaland yielded a value for methyl-substituted alane of $130 \mathrm{~kJ} \mathrm{~mol}^{-1}{ }^{1}$

$D_{0}$ for the other silaylides $\mathrm{RNH}_{2} \rightarrow \mathrm{SiHR}^{\prime}$ are obtained by a two-step procedure. First, the bond dissociation enthalpy relative to that of $\mathrm{NH}_{3} \rightarrow \mathrm{SiH}_{2}, \Delta D_{0}$, is derived as $\Delta H$ at $0 \mathrm{~K}$ for the isodesmic reaction

$$
\begin{array}{r}
\mathrm{RNH}_{2} \rightarrow \mathrm{SiHR}^{\prime}+\mathrm{NH}_{3}+\mathrm{SiH}_{2} \rightarrow \underset{\mathrm{RNH}_{2}+\mathrm{SiHR}^{\prime}+}{\mathrm{NH}_{3} \rightarrow \mathrm{SiH}_{2}}
\end{array}
$$

Then $D_{0}$ for the adduct $\mathrm{RNH}_{2} \rightarrow \mathrm{SiHR}^{\prime}$ is obtained from

$$
\Delta D_{0}=D_{0}\left(\mathrm{RNH}_{2}-\mathrm{SiHR}^{\prime}\right)-D_{0}\left(\mathrm{NH}_{3}-\mathrm{SiH}_{2}\right)
$$

where the $\mathrm{G} 2$ value of $D_{0}\left(\mathrm{NH}_{3}-\mathrm{SiH}_{2}\right)$ is employed. We expect $D_{0}$ derived in this way to be less sensitive to error than calculation of $D_{0}$ directly (also shown in Table 3 ) because errors in calculations below the $\mathrm{G} 2$ level arising

(26) Melius, C. 4-25-93 data, personal communication (1993). The bond dissociation enthalpy at $298 \mathrm{~K}$ has been converted to $0 \mathrm{~K}$. from inadequate basis set size and treatment of changes in correlation energy tend to cancel for reaction 2. Table 4 lists the mean $D_{0}$ values and their uncertainties, which represent an assessment of the scatter between $D_{0}$ values derived from different theoretical levels for a given molecule, combined with the initial uncertainty in the G2 bond strength for $\mathbf{A}$.

As may be seen from Table 4, methyl substitution in $A$ has a small effect on $D_{0}$ and apparently reduces the $\mathrm{Si} \leftarrow \mathrm{N}$ bond strength by only $4 \mathrm{~kJ} \mathrm{~mol}^{-1}$. This might indicate a small degree of electron donation by the methyl group in the silylene into the Si p orbital, which would make donation of the lone pair on $\mathrm{N}$ into this orbital less favorable. Consistent with this idea, the electron-withdrawing $\mathrm{SiH}_{3}$ group induces a slight increase in $D_{0}$, of about $5 \mathrm{~kJ} \mathrm{~mol}^{-1}$. It is reasonable to assume, on the grounds that the environments of the $\mathrm{Si} \leftarrow \mathrm{N}$ bonds are similar in both $\mathrm{CH}_{3}\left(\mathrm{H}_{2}\right) \mathrm{NSi}(\mathrm{H}) \mathrm{CH}_{3}$ and the cyclic molecules $\mathbf{D}, \mathbf{F}$, and $\mathbf{H}$, that the differences in $D_{0}$ may be attributed primarily to strain energy (i.e., strain enthalpy at $0 \mathrm{~K}$ ) in the ring, $E_{\mathrm{S}}$. Here we obtain $E_{\mathrm{S}}$ from

$$
E_{\mathrm{S}} \approx D_{0}\left(\mathrm{H}_{2}\left(\mathrm{CH}_{3}\right) \mathrm{N}-\mathrm{SiHCH}_{3}\right)-D_{0}\left(\mathrm{HSi}\left(\mathrm{CH}_{2}\right)_{x} \mathrm{NH}_{2}\right)
$$

As shown in Table $4, E_{\mathrm{S}}$ is negligible for the fivemembered cyclic silaylide (F), about $6 \mathrm{~kJ} \mathrm{~mol}^{-1}$ for the six-membered ring $(\mathbf{H})$, and $37 \mathrm{~kJ} \mathrm{~mol}^{-1}$ for the fourmembered ring (D). These modest values of $E_{\mathrm{S}}$ can be contrasted to the larger strain energies calculated by Boatz et al. for monosilacycloalkanes, of 103,19 , and $17 \mathrm{~kJ} \mathrm{~mol}^{-1}$ for four-, five-, and six-membered rings, respectively. ${ }^{27}$ The difference arises from the long $\mathrm{Si} \leftarrow \mathrm{N}$ bonds which accommodate larger angles in the carbon framework of the rest of the ring, while at the same time the dative bond into the $\mathrm{p}$ orbital on $\mathrm{Si}$ favors a $90^{\circ}$ angle between the $\mathrm{Si} \leftarrow \mathrm{N}$ bond and other substituents at the $\mathrm{Si}$ atom (see Figure 1). Thus for cyclic $\mathrm{HSi}\left(\mathrm{CH}_{2}\right)_{3} \mathrm{NH}_{2}$ (F) the $\mathrm{NSiC}$ angle is $86.8^{\circ}$ at the RHF/3-21G(*)-optimized geometry, while the $\mathrm{SiCC}, \mathrm{CCC}, \mathrm{CCN}$, and CNSi angles are close to tetrahedral, at $108.1^{\circ}, 105.6^{\circ}, 108.3^{\circ}$, and $108.8^{\circ}$, respectively. One consequence of the small strain energy is that formation of intramolecular $\mathrm{Si} \leftarrow \mathrm{N}$ bonds, as compared to intermolecular bonding, may be reasonably favorable on entropy grounds, without a large opposing enthalpy penalty.

Use of the isodesmic reaction 2 may be inappropriate for $\mathbf{B}$ because it is a more loosely bound complex, and direct $a b$ initio $D_{0}$ values for the second Si $-\mathrm{N}$ bond are qualitatively different from the $D_{0}$ values for the other silaylides (see Table 3 ). This is reflected in the large scatter and uncertainty of the $D_{0}$ values. Nevertheless, the mean $D_{0}$ of $7 \pm 20 \mathrm{~kJ} \mathrm{~mol}^{-1}$ is clearly much smaller than the other values given in Table 4 . The loose $\mathrm{Si}-\mathrm{N}$ bonding in this diamine adduct may not compensate for the entropy loss required for formation of $\mathbf{B}$. Consistent with this possibility, Probst et al. prepared a base-stabilized silylene where two equivalent intramolecular amine groups could bond to $\mathrm{Si}$, but NMR spectroscopy revealed that only one amine was attached at a time. ${ }^{3}$

3.4. UV-Visible Spectroscopy. $S_{0} \rightarrow S_{1}$ transitions in the UV-visible spectrum of silylenes $\mathrm{RSiH}$ arise from $\mathrm{n} \rightarrow \mathrm{p}$ transitions in the Si atom, and the energy of this transition $\Delta E$ is raised if $\mathrm{R}$ is a $\pi$-donor, causing a blue

(27) Boatz, J. A.; Gordon, M. S.; Hilderbrandt, R. L. J. Am. Chem. Soc. $1988,110,352$. 
Table 2. Ab Initio Energies

\begin{tabular}{|c|c|c|c|c|c|c|}
\hline \multirow[b]{2}{*}{ species } & \multicolumn{6}{|c|}{ energy, au ${ }^{a}$} \\
\hline & $\mathrm{HF} / 3-21 \mathrm{G}\left(^{*}\right)$ & $\mathrm{HF} / 6-31 \mathrm{G}^{*}$ & $\begin{array}{c}\mathrm{MP} 2 / 6-31 \mathrm{G}^{*} / / \\
\mathrm{HF} / 6-31 \mathrm{G}^{*}\end{array}$ & $\begin{array}{c}\mathrm{MP} 4 / 6-31 \mathrm{G}^{*} / / \\
\mathrm{HF} / 6-31 \mathrm{G}^{*}\end{array}$ & $\begin{array}{c}\text { MP4/6-311G**// } \\
\text { MP2=FULL/6-31G* }\end{array}$ & Gaussian-2 \\
\hline $\begin{array}{l}\mathrm{NH}_{3} \\
\mathrm{SiH}_{2} \\
\mathrm{H}_{3} \mathrm{NSiH}_{2} \\
\left(\mathrm{H}_{3} \mathrm{~N}\right)_{2} \mathrm{SiH}_{2} \\
\mathrm{CH}_{3} \mathrm{SiH} \\
\mathrm{CH}_{3} \mathrm{NH}_{2} \\
\mathrm{CH}_{3}\left(\mathrm{H}_{2}\right) \mathrm{NSi}(\mathrm{H}) \mathrm{CH}_{3} \\
\mathrm{HSiSiH}_{3} \\
\mathrm{H}_{3} \mathrm{NSi}(\mathrm{H}) \mathrm{SiH}_{3} \\
\text { linear } \mathrm{HSi}\left(\mathrm{CH}_{2}\right)_{2} \mathrm{NH}_{2} \\
\text { cyclic } \mathrm{HSi}\left(\mathrm{CH}_{2}\right)_{2} \mathrm{NH}_{2} \\
\text { linear } \mathrm{HSi}\left(\mathrm{CH}_{2}\right)_{3} \mathrm{NH}_{2} \\
\text { cyclic } \mathrm{HSi}\left(\mathrm{CH}_{2}\right)_{3} \mathrm{NH}_{2} \\
\text { linear } \mathrm{HSi}\left(\mathrm{CH}_{2}\right)_{4} \mathrm{NH}_{2} \\
\text { cyclic } \mathrm{HSi}\left(\mathrm{CH}_{2}\right)_{4} \mathrm{NH}_{2}\end{array}$ & $\begin{array}{l}-55.87220 \\
-288.56027 \\
-344.49445 \\
-400.38236 \\
-327.39861 \\
-94.68166 \\
-422.13739 \\
-577.20378 \\
-633.13982 \\
-420.92471 \\
-420.96689 \\
-459.74448 \\
-459.80151 \\
-498.61899 \\
-498.56319\end{array}$ & $\begin{array}{r}-56.18436 \\
-289.99978 \\
-346.22603 \\
-402.41686 \\
-329.04652^{c} \\
-95.20841^{c} \\
-424.29353^{c} \\
-580.08009^{c} \\
-636.30627^{c}\end{array}$ & $\begin{array}{r}-56.35371 \\
-290.06706 \\
-346.47326 \\
-402.83856 \\
-329.24683^{c} \\
-95.50456^{c} \\
-424.80414^{c} \\
-580.22582^{c} \\
-636.63451^{c} \\
\\
-462.75435^{c} \\
-462.80468^{c}\end{array}$ & $\begin{array}{r}-56.37050 \\
-290.09003 \\
-346.51059 \\
-402.89198\end{array}$ & $\begin{array}{r}-56.42804 \\
-290.13405 \\
-346.61248\end{array}$ & $\begin{array}{l}-56.45865^{b} \\
-290.16771^{b} \\
-346.66335\end{array}$ \\
\hline
\end{tabular}

${ }^{a} 1 \mathrm{au} \approx 2625 \mathrm{~kJ} \mathrm{~mol}^{-1}$. MP2 and MP4 calculations were made with the frozen core approximation unless otherwise noted. ${ }^{b}$ Data from ref 25. c Calculated at the $\mathrm{HF} / 3-21 \mathrm{G}\left({ }^{*}\right)$ geometry.

Table 3. $A b$ Initio Si-N Bond Dissociation Energies

\begin{tabular}{|c|c|c|}
\hline level of calculation & $\begin{array}{c}D_{0} \\
\mathrm{~kJ} \mathrm{~mol}^{-1} a\end{array}$ & $\begin{array}{l}\text { isodesmic } D_{0} \\
\mathrm{~kJ} \mathrm{~mol}^{-1} b\end{array}$ \\
\hline \multicolumn{3}{|c|}{$\mathrm{NH}_{3} \mathrm{SiH}_{2} \rightarrow \mathrm{NH}_{3}+\mathrm{SiH}_{2}$} \\
\hline $\mathrm{HF} / 3-21 \mathrm{G}\left(^{*}\right)$ & 141 & \\
\hline $\mathrm{HF} / 6-31 \mathrm{G}^{*}$ & 91 & \\
\hline $\mathrm{MP} 2 / 6-31 \mathrm{G}^{*} / / \mathrm{HF} / 6-31 \mathrm{G}^{*}$ & 119 & \\
\hline $\mathrm{MP4} / 6-31 \mathrm{G}^{*} / / \mathrm{HF} / 6-31 \mathrm{G}^{*}$ & 112 & \\
\hline$\underset{6-31 \mathrm{G}^{*}}{\mathrm{MP} 4 / 6-311 \mathrm{G}^{* *} / / \mathrm{MP} 2=\mathrm{FULL} /}$ & 113 & \\
\hline Gaussian 2 & 97 & \\
\hline \multicolumn{3}{|c|}{$\left(\mathrm{NH}_{3}\right)_{2} \mathrm{SiH}_{2} \rightarrow \mathrm{NH}_{3}+\mathrm{NH}_{3} \mathrm{SiH}_{2}$} \\
\hline $\mathrm{HF} / 3-21 \mathrm{G}(*)$ & 32 & -12 \\
\hline $\mathrm{HF} / 6-31 \mathrm{G}^{*}$ & 16 & 22 \\
\hline $\mathrm{MP} 2 / 6-31 \mathrm{G}^{*} / / \mathrm{HF} / 6-31 \mathrm{G}^{*}$ & 29 & 7 \\
\hline $\mathrm{MP4} / 6-31 \mathrm{G}^{*} / / \mathrm{HF} / 6-31 \mathrm{G}^{*}$ & 27 & 12 \\
\hline \multicolumn{3}{|c|}{$\mathrm{CH}_{3}\left(\mathrm{H}_{2}\right) \mathrm{NSi}(\mathrm{H}) \mathrm{CH}_{3} \rightarrow \mathrm{CH}_{3} \mathrm{NH}_{2}+\mathrm{HSiCH}_{3}$} \\
\hline $\mathrm{HF} / 3-21 \mathrm{G}\left({ }^{*}\right)$ & $13 \overline{3}$ & 89 \\
\hline $\left.\mathrm{HF} / 6-31 \mathrm{G}^{*} / / \mathrm{HF} / 3-21 \mathrm{G}^{*}\right)$ & 84 & 90 \\
\hline $\mathrm{MP} 2 / 6-31 \mathrm{G}^{*} / / \mathrm{HF} / 3-21 \mathrm{G}\left({ }^{*}\right)$ & 121 & 99 \\
\hline \multicolumn{3}{|c|}{$\mathrm{H}_{3} \mathrm{NSi}(\mathrm{H}) \mathrm{SiH}_{3} \rightarrow \mathrm{NH}_{3}+\mathrm{HSiSiH}_{3}$} \\
\hline $\mathrm{HF} / 3-21 \mathrm{G}\left({ }^{*}\right)$ & 149 & 105 \\
\hline $\mathrm{HF} / 6-31 \mathrm{G}^{*} / / \mathrm{HF} / 3-21 \mathrm{G}\left(^{*}\right)$ & 91 & 97 \\
\hline $\left.\mathrm{MP} 2 / 6-31 \mathrm{G}^{*} / / \mathrm{HF} / 3-21 \mathrm{G}^{*}\right)$ & 126 & 104 \\
\hline \multicolumn{3}{|c|}{ Ring Opening in $\mathrm{HSi}\left(\mathrm{CH}_{2}\right)_{2} \mathrm{NH}_{2}$} \\
\hline $\mathrm{HF} / 3-21 \mathrm{G}\left({ }^{*}\right)$ & 101 & 57 \\
\hline \multicolumn{3}{|c|}{ Ring Opening in $\mathrm{HSi}\left(\mathrm{CH}_{3}\right)_{2} \mathrm{NH}_{2}$} \\
\hline $\mathrm{HF} / 3-21 \mathrm{G}\left({ }^{*}\right)$ & 136 & 92 \\
\hline $\mathrm{HF} / 6-31 \mathrm{G}^{*} / / \mathrm{HF} / 3-21 \mathrm{G}\left(^{*}\right)$ & 87 & 93 \\
\hline $\mathrm{MP} 2 / 6-31 \mathrm{G}^{*} / / \mathrm{HF} / 3-21 \mathrm{G}\left(^{*}\right)$ & 119 & 97 \\
\hline \multicolumn{3}{|c|}{ Ring Opening in $\mathrm{HSi}\left(\mathrm{CH}_{4}\right)_{2} \mathrm{NH}_{2}$} \\
\hline $\mathrm{HF} / 3-21 \mathrm{G}\left(^{*}\right)$ & 132 & 88 \\
\hline
\end{tabular}

a Bond dissociation enthalpy at $0 \mathrm{~K}$, which includes changes in zeropoint energies. ${ }^{b} D_{0}$ obtained via consideration of the isodesmic reaction 2 (see text).

shift in the electronic spectrum. ${ }^{16}$ Among the substituents considered by Apeloig and Karni, $\mathrm{R}=\mathrm{NH}_{2}$ caused the greatest increase in $\Delta E, 147 \mathrm{~kJ} \mathrm{~mol}^{-1} .16$ We have employed their HF approach and also the CIS method, outlined in section 2, to derive the $S_{0} \rightarrow S_{1}$ transition energies listed in Table 5, together with the blue shifts relative to the $\mathrm{SiH}_{2}$ absorption. It may be seen that the derived $\Delta E$ values are not strongly basis-set dependent. An approximate indication of the likely uncertainty in calculated wavelengths may be obtained via consideration of the $\mathrm{HSiCH}_{3}$ and $\mathrm{Si}\left(\mathrm{CH}_{3}\right)_{2}$ molecules. $\lambda \approx 480 \mathrm{~nm}$ has been measured for $\mathrm{HSiCH}_{3},{ }^{28}$ while the HF result of Apeloig and Karni ${ }^{16}$ is $509 \mathrm{~nm}$ and our CIS results is $463 \mathrm{~nm}$. For $\mathrm{Si}\left(\mathrm{CH}_{3}\right)_{2}$ the
Table 4. Estimated Bond Energies and Strain Energies^

\begin{tabular}{lrc}
\hline \multicolumn{1}{c}{ molecule } & $\begin{array}{c}\text { estimated } D_{0}, \\
\mathrm{~kJ} \mathrm{~mol}^{-1}\end{array}$ & $\begin{array}{c}\text { strain energy, } \\
\mathrm{kJ} \mathrm{mol}^{-1}\end{array}$ \\
\hline $\mathrm{H}_{3} \mathrm{NSiH}_{2}$ & $97 \pm 10$ & \\
$\left(\mathrm{H}_{3} \mathrm{~N}\right)_{2} \mathrm{SiH}_{2}$ & $7 \pm 20$ & \\
$\left(\mathrm{CH}_{3}\right) \mathrm{HSiN}\left(\mathrm{CH}_{3}\right) \mathrm{H}_{2}$ & $93 \pm 15$ & \\
$\mathrm{H}_{3} \mathrm{NSi}(\mathrm{H}) \mathrm{SiH}_{3}$ & 102.15 & \\
cyclic $\mathrm{HSi}\left(\mathrm{CH}_{2}\right)_{2} \mathrm{NH}_{2}$ & $57 \pm 15$ & 37 \\
cyclic $\mathrm{HSi}\left(\mathrm{CH}_{2}\right)_{3} \mathrm{NH}_{2}$ & $94 \pm 15$ & -1 \\
cyclic $\mathrm{HSi}\left(\mathrm{CH}_{2}\right)_{4} \mathrm{NH}_{2}$ & $88 \pm 15$ & 6
\end{tabular}

a See text for discussion of estimation methods.

Table 5. Calculated Energy Difference between $S_{0}$ and $S_{1}$ States, $\Delta E$, and Wavelength Shift Relative to Silylene from HF and CIS Theory

\begin{tabular}{|c|c|c|c|c|c|}
\hline \multirow[b]{2}{*}{ species } & \multirow[b]{2}{*}{$\left\langle S^{2}\right\rangle^{b}$} & \multicolumn{2}{|c|}{ Hartree-Fock results } & \multicolumn{2}{|c|}{$\begin{array}{c}\text { configuration } \\
\text { interaction } \\
\text { results }\end{array}$} \\
\hline & & $\underset{\mathrm{kJ} \mathrm{mol}^{-1}}{\Delta E}$ & $\begin{array}{l}\text { blue } \\
\text { shift, } \\
\mathrm{nm}^{c}\end{array}$ & $\underset{\mathrm{kJ} \mathrm{mol}^{-1}}{\Delta E,}$ & $\begin{array}{l}\text { blue } \\
\text { shift, } \\
\text { nm }^{d}\end{array}$ \\
\hline $\mathrm{SiH}_{2}$ & 1.034 & $\begin{array}{c}225, e 225 f \\
224^{g}\end{array}$ & 0 & 247 & 0 \\
\hline $\begin{array}{l}\mathrm{HSiCH}_{3} \\
\mathrm{Si}\left(\mathrm{CH}_{3}\right)_{2}\end{array}$ & & $\begin{array}{l}235 g \\
2428\end{array}$ & $\begin{array}{l}24 \\
40\end{array}$ & $\begin{array}{l}259 \\
278\end{array}$ & $\begin{array}{l}22 \\
54\end{array}$ \\
\hline $\mathrm{HSiSiH}_{3}$ & 1.044 & $157, e 1538$ & $\begin{array}{l}-230 \\
-250\end{array}$ & 187 & -156 \\
\hline $\begin{array}{l}\mathrm{Si}\left(\mathrm{SiH}_{3}\right)_{2} \\
\mathrm{HSiNH}_{2}\end{array}$ & 1.034 & $\begin{array}{l}126^{e} \\
3678\end{array}$ & $\begin{array}{l}-417 \\
206\end{array}$ & & \\
\hline $\mathrm{H}_{3} \mathrm{NSiH}_{2}$ & 1.012 & $474,^{e} 441^{f}$ & $\begin{array}{l}279 \\
261\end{array}$ & 398 & 184 \\
\hline $\begin{array}{l}\left(\mathrm{H}_{3} \mathrm{~N}\right)_{2} \mathrm{SiH}_{2} \\
\mathrm{H}_{3} \mathrm{NSi}(\mathrm{H}) \mathrm{SiH}_{3}\end{array}$ & 1.015 & $496^{f}$ & 291 & 370 & 160 \\
\hline $\begin{array}{l}\text { linear } \mathrm{HSi}\left(\mathrm{CH}_{2}\right)_{3} \mathrm{NH}_{2} \\
\text { cyclic } \mathrm{HSi}\left(\mathrm{CH}_{3}\right)_{3} \mathrm{NH}_{2}\end{array}$ & $\begin{array}{l}1.036 \\
1.012\end{array}$ & $\begin{array}{l}241^{e} \\
485^{e}\end{array}$ & $\begin{array}{l}35 \\
285\end{array}$ & $\begin{array}{l}257 \\
407\end{array}$ & $\begin{array}{r}19 \\
191\end{array}$ \\
\hline
\end{tabular}

${ }^{a} \mathrm{CIS} / 6-31+\mathrm{G}^{*}$ data. ${ }^{b}$ For the UHF wave function of the $S_{1}$ state. c Relative to a theoretical $\lambda=532 \mathrm{~nm}$ for the $S_{0} \rightarrow S_{1}$ transition of $S_{i H}$. ${ }^{d}$ Relative to a theoretical $\lambda=485 \mathrm{~nm}$ for the $\mathrm{S}_{0} \rightarrow \mathrm{S}_{1}$ transition of $\mathrm{SiH}_{2}$. e At the HF/3-21G $\left(^{*}\right)$ level. $f$ At the HF/6-31G* level. 8 From ref 16 , at the $\mathrm{HF} / 6-31 \mathrm{G}^{*}$ level.

$S_{0} \rightarrow S_{1}$ absorption maximum of $\lambda \approx 494 \mathrm{~nm}$ calculated by Apeloig and Karni ${ }^{16}$ at the HF level can be compared with our CIS result of $\lambda \approx 431 \mathrm{~nm}$ and the result of Grev and Schaefer ${ }^{29}$ of $\lambda \approx 450 \mathrm{~nm}$ obtained through more extensive calculations, which is in accord with experimental values of $450-460 \mathrm{~nm} \cdot{ }^{28,30-32}$ A small blue shift of $35 \mathrm{~nm}$

(28) Maier, G.; Mihm, G.; Reisenauer, H. P.; Littmann, D. Chem. Ber. $1984,117,2369$.

(29) Grev, R. S.; Schaefer, H. F., III. J. Am. Chem. Soc. 1986, $108,5804$. 
relative to $\mathrm{SiH}_{2}$ for linear $\mathrm{HSi}\left(\mathrm{CH}_{2}\right)_{3} \mathrm{NH}_{2}(\mathrm{E})$ is estimated at the HF level, comparable to those predicted earlier for methyl and dimethylsilylene, ${ }^{16}$ and may be attributed to small electron donation from the alkyl group. At the CIS level we find a blue shift of $19 \mathrm{~nm}$. For $\mathrm{HSiSiH}_{3}$ the HF calculations predict $\lambda \approx 770 \mathrm{~nm}$, whereas the CIS result is $641 \mathrm{~nm}$. The latter is much closer to the recently observed $\lambda$ in several trimethylsilyl silylenes. ${ }^{20}$

At the HF level, dative bonding in $\mathbf{A}$ is predicted to increase $\Delta E$ by about $249 \mathrm{~kJ} \mathrm{~mol}^{-1}\left(3-21 \mathrm{G}\left({ }^{*}\right)\right)$ or $216 \mathrm{~kJ}$ $\mathrm{mol}^{-1}\left(6-31 \mathrm{G}^{*}\right)$, which implies a large blue shift in absorption wavelength of around $270 \mathrm{~nm}$. These changes in $\Delta E$ are seen to be overestimates by comparison with the observations of Ando et al. ${ }^{13}$ and Gillette et al. ${ }^{14}$ which correspond to increases in $\Delta E$ of approximately $150 \mathrm{~kJ}$ $\mathrm{mol}^{-1}$ upon complexation of silylenes with amines. The CIS change in $\Delta E, 151 \mathrm{~kJ} \mathrm{~mol}^{-1}$, corresponds to a decrease of $\lambda$ from 485 to $301 \mathrm{~nm}$ and is in excellent agreement with experiment. Thus overall the CIS method appears to be more accurate than the HF approach and gives good accord with the observed spectra. The CIS method predicts a similar increase in $\Delta E$ for formation of the cyclic silaylide F.

Conlin and co-workers have prepared phenyl trimethylsilyl silylenes photolytically in a frozen 3-methylpentane matrix. ${ }^{20}$ That work indicates that if an amine group is available for intramolecular coordination to $\mathrm{Si}$ in a fivemembered ring, then the absorption band is shifted from 660 to $480 \mathrm{~nm}$, i.e., $\Delta E$ is increased by about $68 \mathrm{~kJ} \mathrm{~mol}^{-1}$. This is smaller than but in qualitative accord with the predicted shift in $\Delta E$ at the HF and CIS levels in the five-membered ring $(\mathbf{F})$; the discrepancy with the larger change in $\Delta E$ predicted here may reflect the influence of the phenyl and trimethylsilyl groups. Consistent with this interpretation, the CIS result for $\mathrm{HSiSiH}_{3}$ complexed with $\mathrm{NH}_{3}$ demonstrates that a silyl group somewhat reduces the blue shift in $\lambda$ (relative to $\mathrm{SiH}_{2}$ ) caused by complexation: quantitative analysis of the combined influence of phenyl and trimethylsilyl groups remains a topic for future investigation.

3.5. Kinetic Implications. Initial experimental evidence ${ }^{20}$ is that the reactions of the possible cyclic silaylide with known trapping agents for silylenes yield the same

(30) Drahnak, T. J.; Michl, J.; West, R. J. Am. Chem. Soc. 1979, 101, 5427.

(31) Vančik, H.; Raabe, G.; Michalczyk, M. J.; West, R.; Michl, J. J. Am. Chem. Soc. 1985, 107, 4097.

(32) Baggott, J. E.; Blitz, M. A.; Frey, H. M.; Lightfoot, P. D.; Walsh, R. Chem. Phys. Lett. 1987, 135, 39. products as would be expected from the silylene. There are alternative modes for trapping reactions with a silaylide, either that the silaylide first dissociates to the free silylene, or that $\mathrm{Si} \leftarrow \mathrm{N}$ bond fission is concerted with attack on the trap. A crude upper bound to the dissociation rate constant of the five-membered cyclic silaylide $(F)$ is obtained by assuming that the activation energy is equal to $D_{0}$ and that the preexponential factor might be as large as $10^{17} \mathrm{~s}^{-1}$. This implies a room temperature rate constant of at most about $10 \mathrm{~s}^{-1}$, which is too small to account for the observations. ${ }^{20}$ A similar result is derived from the $D_{0}$ value of Raghavachari $e t$ al., ${ }^{4}$ and an even smaller upper bound to the dissociation rate constant would be obtained if the slight bond-strengthening effect (Table 4) of $\mathrm{SiH}_{3}$ substitution (in the experimental silaylide ${ }^{20}$ ) were taken into account. This lends support to the idea of a concerted reaction and suggests that the silaylides may react as hypercoordinated silylenes. In the absence of a trapping agent, the theoretical work of Raghavachari et al. ${ }^{4}$ suggests that a possible fate of silylene complexes with primary or secondary amines is isomerization to a more stable silylamine. Gillette et al..$^{14}$ found, in the case of adducts to tertiary amines, that disilenes were ultimately formed, probably either by dimerization of two complexes or by reaction of a complex with a free silylene.

\section{Conclusions}

The geometries and vibrational and electronic properties of dative $\mathrm{Si} \leftarrow \mathrm{N}$ bonds formed between silylenes and amines have been estimated. The thermochemistry has been investigated, and the best estimate of the $\mathrm{H}_{3} \mathrm{~N} \rightarrow \mathrm{SiH}_{2}$ bond strength is $D_{0} \approx 97 \pm 10 \mathrm{~kJ} \mathrm{~mol}^{-1}$ from G2 theory. This value is used to derive $D_{0}$ for other silaylides via isodesmic reactions. The strain energies in cyclic silaylides were shown to be small. Two $\mathrm{NH}_{3}$ molecules may be coordinated to $\mathrm{SiH}_{2}$, and the resulting second $\mathrm{Si}-\mathrm{N}$ bonds are predicted to be weak, with $D_{0} \approx 7 \pm 20 \mathrm{~kJ} \mathrm{~mol}^{-1}$. $\mathrm{S}_{0}$ $\rightarrow \mathrm{S}_{1}$ energies have been calculated for several silylenes, including ones complexed to amine groups, and good agreement between CIS/6-31+G* results and experimental $\mathrm{UV}$-visible spectra is found.

Acknowledgments. D.L. Thanks the Department of Chemistry and the Texas Academy of Mathematics and Science for a Minority Student Research Fellowship. This work was supported by the Robert A. Welch Foundation (Grants B-0778 and B-1174), Texas Instruments, Inc., and the UNT Organized Research Fund.

OM9306584 